\title{
Mental health actions and nurse's work
}

\author{
Ações de saúde mental e o trabalho do enfermeiro \\ Acciones de salud mental y el trabajo de la enfermera
}

Janaína Cristina Pasquini de Almeida' ORCID: 0000-0003-0331-0365

Celma Aparecida Barbosa'

ORCID: 0000-0002-5112-1385

Letícia Yamawaka de Almeida' ORCID: 0000-0002-5192-6052

Jaqueline Lemos de Oliveira' ORCID: 0000-0003-3699-0280

Jacqueline de Souza' ORCID: 0000-0002-6094-6012

'Universidade de São Paulo. Ribeirão Preto, São Paulo, Brazil.

How to cite this article: Almeida JCP, Barbosa CA, Almeida LY, Oliveira JL, Souza J. Mental Health Actions and Nurse's Work.

Rev Bras Enferm. 2020;73(Suppl 1):e20190376. doi: http://dx.doi.org/10.1590/0034-7167-2019-0376

Corresponding author: Jaqueline Lemos de Oliveira E-mail: jaquelemos@usp.br

EDITOR IN CHIEF: Antonio José de Almeida Filho ASSOCIATE EDITOR: Margarida Vieira

Submission: 09-06-2019 Approval: 04-27-2020

\begin{abstract}
Objective: to analyze the perception of nurses and other members of the patient care team about nurses' actions in mental health care. Methods: the study was conducted with professionals from mental health services in the interior of the state of São Paulo. The data collected through semi-structured interviews, a questionnaire with closed questions and a focus group were submitted to content analysis. Results: the participants referred mainly to the nursing care with the body and physical health, but also identified the nurse as a "gateway" for care, facilitator and integrator of actions and as the professional who has more contact with the user. Final considerations: although the stereotype of nursing as "body caregiver" refers to the beginnings of psychiatric nursing, the perception of the participants showed aspects that suggest a change in relation to the role traditionally attributed to this profession. Descriptors: Nursing Care; Nurses; Mental Health; Work; Patient Care Team.
\end{abstract}

\section{RESUMO}

Objetivo: analisar a percepção de enfermeiros e demais membros da equipe multiprofissional sobre as ações do enfermeiro no cuidado de saúde mental. Métodos: o estudo foi realizado com profissionais de serviços de saúde mental do interior de São Paulo. Os dados coletados por meio de entrevistas semiestruturadas, questionário com perguntas fechadas e grupo focal foram submetidos à análise de conteúdo. Resultados: os participantes referiram, principalmente, os cuidados de enfermagem com o corpo e a saúde física, mas também identificaram o enfermeiro como "porta de entrada" para o cuidado, facilitador e integrador de ações e como o profissional que tem mais contato com o usuário. Considerações finais: embora o estereótipo da enfermagem como "cuidadora do corpo" remeta aos primórdios da enfermagem psiquiátrica, a percepção dos participantes denotou aspectos que sugerem mudança em relação ao papel tradicionalmente atribuído a esta profissão.

Descritores: Cuidados de Enfermagem; Enfermeiro; Saúde Mental; Trabalho; Equipe Interdisciplinar de Saúde.

\section{RESUMEN}

Objetivo: analizar la percepción de las enfermeras y otros miembros del equipo multidisciplinario sobre las acciones de las enfermeras en la atención de la salud mental. Métodos: el estudio se realizó con profesionales de servicios de salud mental en el interior del estado de São Paulo. Los datos recopilados a través de entrevistas semiestructuradas, un cuestionario con preguntas cerradas y un grupo focal fueron sometidos a análisis de contenido. Resultados: los participantes se refirieron principalmente al cuidado de enfermería con el cuerpo y la salud física, pero también identificaron a la enfermera como una "puerta de entrada" para el cuidado, facilitadora e integradora de acciones y como el profesional que tiene más contacto con el paciente. Consideraciones finales: aunque el estereotipo de enfermería como "cuidador del cuerpo" se refiere a los inicios de la enfermería psiquiátrica, la percepción de los participantes mostró aspectos que sugieren un cambio en relación con el papel tradicionalmente atribuido a esta profesión.

Descriptores: Atención de Enfermería; Enfermera; Salud Mental; Trabajo; Grupo de Atención al Paciente. 


\section{INTRODUCTION}

The practice of psychiatric nursing was constituted concurrently with the emergence of the first hospitals. Initially, lay people, servants and ex-inmates performed this mid-level function of "nursing", at the time characterized by the surveillance and coercion of inmates.

In the 18th century, marked by Pinel moral treatment, nursing actions were subordinated to psychiatric knowledge, that is, those who performed such actions were responsible for preparing the "body" to be examined by the doctor. In addition, they should keep a watchful eye on food, hygiene, sleep, aggressive behavior, referrals to the external courtyard and ensure the maintenance of institutional order ${ }^{(1)}$.

Initiatives to change the biomedical care model to the biopsychosocial paradigm have gradually required changes in the role of nursing in the field of mental health.

Previous studies have investigated nursing actions in this area, highlighting actions such as identifying biopsychosocial-spiritual needs through interpersonal communication; consideration of verbal and non-verbal expressions in the user's assessment; demonstration of empathy; stimulating the individuals' autonomy; co-responsibility for their health production; self-reflection about their practice; and collectivization of assistance in a patient care team and in the development of a unique therapeutic project ${ }^{(2-4)}$. Despite such studies, the core actions of the profession, that is, specific to nurses in mental health, still need to be defined.

Thus, this study is based on the following research question: What are the specific actions of nurses in the context of mental health?

\section{OBJECTIVE}

To analyze the perception of nurses and other members of the patient care team about the nurses' actions in mental health care.

\section{METHODS}

\section{Ethical aspects}

The study complied with the principles of Resolution No. 466 of the National Health Council, of December 12, 2012, being approved by the Research Ethics Committee of the Ribeirão Preto School of Nursing, under opinion No. 2,248,068. All participants signed the Free and Informed Consent Form (FICF).

\section{Type of study}

It is a descriptive, cross-sectional and qualitative study guided by the COREQ tool.

\section{Scenario of study}

The study scenario was a medium-sized municipality, located in the Midwest of the state of São Paulo, $345 \mathrm{~km}$ from the capital. In the health sector, the municipality is qualified in Full Management of Extended Primary Care (Portuguese acronym: Paba), according to the Operational Norm of Health Care.
Data collection was carried out in all mental health services in the city, namely: Mental Health Outpatient Clinic (Portuguese acronym: ASM), Psychosocial Care Center for Alcohol and other Drugs (Portuguese acronym: CAPS AD), Child Psychosocial Care Center (Portuguese acronym: CAPS i), Child Psychosocial Care Center I (Portuguese acronym: CAPS I) and Children and Adolescents Psychosocial Care Center for Alcohol and other Drugs III (Portuguese acronym: CAPS AD i III).

These are community-based services, composed of a patient care team that serves the population with specific demands of mental health (mental illness, emotional distress or problems related to the use of psychoactive substances).

\section{Data source}

In the period in which the data were collected, each service had 15 to 25 professionals, totaling 88 workers, of which 10 were nurses. The eligibility criteria were working in the municipality's health network for more than six months, and exclusion criteria being on leave of absence or on vacation during the data collection period. All professionals met the eligibility criteria and, therefore, were invited to participate in the study during a team meeting held in each of these services. The final sample consisted of 33 (37.5\%) professionals who agreed to participate in the study, six of them nurses. Such sample had at least one representative from each professional category of medium and/or higher level.

\section{Data collection and organization}

Data were collected by a nurse trained for this purpose over a 48-hour course taught at the Ribeirão Preto School of Nursing of University of Sao Paulo. (USP). Such collection took place from July to September 2017, in the health services themselves, at times previously agreed with each participant. Three different data collection techniques were used, namely: semi-structured interview, structured questionnaire and focus group.

\section{Work stages}

Initially, semi-structured interviews, the first data collection technique, were conducted with nurses, aiming to apprehend the specific perception of these professionals in relation to their own practice. A script was used with the following guiding questions: "Tell me about your daily life in this service"; "What is your perception of the nurse's role in mental health care?".

To test the script, two pilot interviews were conducted, through which it was identified that the answers to the second question, in some cases, were vague. For this reason, an additional question was added to the script: "How would you explain the role of the nurse in the multidisciplinary mental health team to a public manager?".

The interviews were carried out in a place in agreement with the six participating nurses and previously scheduled, so as not to disturb the work process.

In the second technique, a questionnaire was applied to all participants, asking them to indicate the alternative that best 
expressed their perceptions about who was responsible for carrying out certain health actions. The questionnaire was developed based on the specific mental health actions described in the Nursing Interventions Classification (NIC) and in the International Classification of Nursing Practice in Public Health (CIPESC). In addition, the psychosocial actions recommended for mental health care by the authors Costa-Rosa (2000) and Saraceno (1999) (5-6) were considered (1999) ${ }^{(5-6)}$.

The questionnaire was submitted to the evaluation of four judges from another municipality, being an clinical nurse from CAPS, a mental health specialist nurse with research experience, a psychiatric nursing research nurse and a coordinating psychologist from CAPS.

The final version of this instrument contained six dimensions: organization of the work process, technical-administrative and organizational activities, activities related to social participation, individual care, work process and practices in the territory. Each contained, respectively, 20, 12, seven, 36, 15 and six health actions. The response options were: 1) nurse's specific actions; 2 ) action by any member of the patient care team; 3 ) action of responsibility of higher education professionals; and 4) action by another professional (specify which one). Only alternatives one and four could be checked concurrently. Participants had a period of one week to return the completed instrument.

The last technique of data collection was the realization of the focus group, to which all participants were invited. A nurse, a social worker, two psychologists, a social worker, a nursing technician and cleaning assistant, representing three of the five services included in this study.

The purpose of this technique was to explore the different perceptions about the nurse's work in mental health. The conduct of the group started from the following guiding questions: "How do you perceive the work of nurses in the mental health team?" "Which actions are specific to the nurse and which are related to multidisciplinary work?" The group was led by the principal researcher, who also noted the impressions in a field diary at the end of the session. The group was carried out in one of the mental health services, strategically located close to the others.

\section{Data analysis}

For data analysis, we used the content analysis technique ${ }^{(7)}$. The interviews and the focus group were audio recorded and transcribed in full, composing a corpus of information. Successive and in-depth readings of the material were undertaken to identify units of meaning.

From the codification of the information, it was identified that the interdisciplinary character in mental health care was the central element in the results. The codes were grouped into categories considering the participants' different perceptions about the nurses' core and field actions in mental health care. Therefore, the categories generated were: 1 ) the nurse's work in the patient care team and 2) the nurse's identity in the patient care team.

The analytical stage was undertaken by the main researcher, master's student and clinical nurse at a mental health service, and by her advisor. The relevance of the master's student being a nurse, having elaborated the research proposal and participating in both data collection and analysis is a factor that deserves to be highlighted in terms of reflexivity, because, in the same way that it positively influenced the development of research, it can also cause some bias in the analysis.

In this sense, we opted for the triangulation of analysts, that is, interpretation of the data by more than one analyst, which favors the verification of the blind spots of a single interpretation and contributes to the control of possible biases ${ }^{(8-9)}$. That is, the data analysis was processed by two nurse researchers who compared their interpretations to guarantee precision and reliability to the results. More than $80 \%$ of the interpretations generated were similar between both researchers. The dissimilarities were also considered and debated in meetings with the other authors of the study, to resolve and/or reconceptualize the findings and articulate them with the adopted framework.

It should be noted that during the process of coding, characterizing and interpreting the data, the characteristics of each of the participants in the corresponding statements were considered, to ascertain possible influence or interference of their personal and professional specificities in relation to the expressed perception. However, there was no evidence of any influence in this sense during the analytical process by any of the analysts involved, nor during discussions with the other authors.

The concepts of "field" and "core" developed by Campos (2000) (10) were used as a reference for the analysis. The author starts from the notion that collective health is an attempt to overcome the hegemonic model based on medical specialties, to another that favors the social co-participation of the individuals in the "production of social needs".

In this logic, it is understood that most scientific fields admit an interdisciplinary and multiprofessional practice and, therefore, it is possible to use the concepts of field and core in the discussion about collective health ${ }^{(10)}$.

Thus, "core" is conceived as the set of specific skills and knowledge of each professional, that is, the specific role of competencies for each profession. The "field" consists of the set of knowledge and responsibilities that are common or confluent with various specialties $^{(10)}$. Thus, such concepts were used in the present study to discuss nurses' actions in mental health care considering their professional identity and interdisciplinary practice.

The questionnaire data were entered into a Microsoft Excel version 2010 spreadsheet and analyzed using descriptive statistics. Subsequently, the questionnaire data were cross-checked with the categories derived from the content analysis of the other data corpus.

\section{RESULTS}

Regarding the sociodemographic characterization of the participants (Table 1), the majority were female and had completed a college degree, recently completed a graduate studies/ specialization course and work in the care area with exclusive dedication to the mental health service.

Figure 1 presents the summary of the results of the categories generated. 
Table 1 - Sociodemographic data of the participants, Interior of São Paulo São Paulo, Brazil 2017

\begin{tabular}{ll}
\hline Sociodemographic variables & $\mathbf{n}(\%)$ \\
\hline Age & \\
$30-40$ years & $15(45)$ \\
$40-50$ years & $9(27)$ \\
$50-60$ years & $9(27)$ \\
Gender & \\
Female & $25(76)$ \\
Male & $8(24)$ \\
Level & \\
Technician & $11(33)$ \\
Higher & $22(67)$ \\
Graduate studies & \\
Yes & $22(67)$ \\
No & $11(33)$ \\
Graduate course in mental health & \\
Sim & $16(48)$ \\
No & $17(52)$ \\
Last course year & \\
2012 & $1(3)$ \\
2016 & $2(6)$ \\
2017 & $20(61)$ \\
Did not take course & $10(30)$ \\
Last course area & \\
Mental health & $16(48)$ \\
Others & $7(21)$ \\
Did not take course & $10(30)$ \\
Job title & \\
Coordinator & \\
Assistance & \\
Administrative (Not coordinator) & \\
Profession & $2(6)$ \\
Nurse & \\
Other professionals & $3(9)$ \\
Works in other locations & \\
Yes & $6(18)$ \\
No & $27(82)$ \\
\hline & $10(30)$ \\
& $23(70)$ \\
\hline
\end{tabular}

In this sense, mental health services have been described as points of attention where it is possible to clearly see interdisciplinary work and as learning spaces for the consolidation of this work:

I worked in primary care and went to mental health, I started to like mental health a lot. So it seems that I saw the issue of interdisciplinarity, even with all the difficulties, because in the basic unit everything was very fragmented, each one doing only his/her specific work. (Participant Social Worker 1/focus group)

Working in mental health makes the nurse better understand what an interdisciplinary, multidisciplinary team and interdisciplinary work is, because when we come from the fist-aid post, basic unit, hospital, we are more focused, more centralized in "nursing and doctor". (Nurse 1/interview)

Health promotion activities, conducting therapeutic groups and workshops, active listening, establishing bonds, observing behaviors and identifying the effects of medications were the actions discriminated as interdisciplinary, that is, the competence of both nurses and other team members.

Nurses also mentioned, as interdisciplinary activities, triage, reception, home visits, playful activities and social interaction (games, films, painting, drawings, etc.) and conflict mediation. In addition, they considered that service coordination, student tutoring, matrix support, reference and counter-reference of users to other services in the network, policy making, technical projects and reports, interdisciplinary consultation, formulation and monitoring of the Singular Therapeutic Project (STP) and acting as a reference professional were actions within the competence of all higher education professionals.

The reception was another action considered interdisciplinary, but the participants identified the nurse as the "gateway" for care, as he was always present during the entire hours of operation of mental health services and for having more

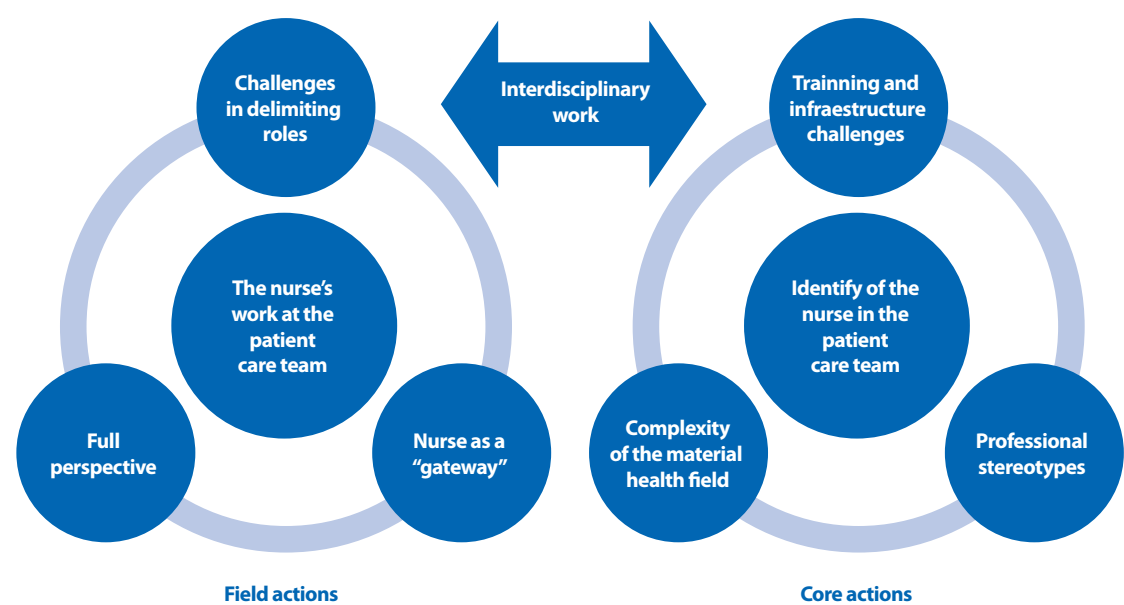

Figure 1 - Summary of results according to categories, interior of São Paulo, Brazil, 2017 contact with the user. Nurses described themselves as a reference for both the user and the team that used nursing in different situations:

The patient is sick, they will not call the psychologist, they will call the nursing or the nurse and then they will get the nurse. The patient is sleepy, then the nurse is called, the patient has an epileptic seizure, then the nurse is called. So that part of the patient is not well clinically, or demonstrating that he/she will have a crisis, an outbreak, then the nurse is called. (Nurse 4/interview)

Both in the focus group and in the interviews, it was mentioned that the nurse acted as a "facilitator" and "integrator of actions":

\section{The nurse's work in the patient care team}

Most participants (79\%) emphasized interdisciplinarity as a central element in the work process of professionals in mental health services, reaffirming that all team members could contribute to the integration of care.
The main role of the nurse I think is to be the facilitator of the story, because he/she will take the medical action and transform for the patient, psychological action for the patient, social action for the patient and from the patient to that, to the doctor, to the other nurse colleague, to the social, to the psychological. I think it is like being the facilitator of the story, being able to get a little 
bit of each one. Because everything ends up involving nursing. (Participant Nursing Technician 4/focus group)

The focus group discussions also highlighted the comprehensive perspective of nursing:

In the nursing consultation you will see the whole, in the nursing consultation what is different is that you will analyze the psychosocial context of that person to see what its reflection in this body is. (Participant Social Worker 1/focus group)

Because nursing is also involved in the social, in the workshops they help us, it is support for us too. (Participant Social Worker 6/focus group)

Nurses themselves also recognized their practice from this comprehensive perspective:

The nursing sees the client, the patient in general, no other professional can see that. No other professional can see all sides of that individual. (Nurse 5/focus group)

A nurse is a very important person, he/she knows how to manage, he/she is the eyes of the administrator, because all areas he/she does well, everything he/she observes, if you put a nurse, he/she will see the laundry, he/she will know how the kitchen works, he/ she will know how to place the reception, how the reception is, how the first-aid post is. (Nurse 5/interview)

Despite this, nurses cited the difficulty of working in a patient care team, as they had to carry out actions that they did not consider to be their competence and for not perceiving a clear delimitation of the attributions of each profession:

Within a multidisciplinary, multi-professional team, you end up doing things that would not be your competencies, but, within this routine, they end up being necessary, understand? (Nurse 6/interview)

I think that everyone here does practically the same things, unfortunately, so there is no certainty about what belongs to one, what belongs to another. (Nurse 5/interview)

On the other hand, other members of the patient care team reported difficulties in understanding the role of nurses in mental health and in differentiating the core actions from other professions of the team:

But I think we find it difficult to understand what is specific to nurses [...] as well as not everyone who knows what the psychologist does. (Participant Psychologist 2/focus group)

\section{Identity of the nurse in the patient care team}

Despite the mention of interdisciplinarity as a primary character of mental health care, stereotyped notions about the attributions of each profession were cited by the participants as a challenge for teamwork:

But it is always the social worker who works with poverty, a food basket, the psychologist will only take care of the crazy person, the nurse who enters the body. Then, there are professional jargon. Socially, nurses are expected, due to their social construction, training and history, to take care of the body, only the body. It is very important that there are people who take care of this body with quality. (Participant Social Worker 1 /focus group)

In our practice, we still have expectations of the nurse who takes care only of the biological. It's the stigma, right. The psychologist who enters people's heads and guesses the thought, right. (Participant Psychologist 2/focus group)

In relation to the nurse's work, body care and the demands described by the teams as "biological actions" were emphasized. Technical procedures in which there is direct contact with the "physical body", such as blood collection, medication administration, anthropometric measurement, verification of vital signs, monitoring of glucose levels, treatment of wounds and first aid care, were attributed to nursing team, mainly the nurse, by more than $85 \%$ of the participants.

In addition, in the interviews, "physical health" was mentioned by nurses as being a specific feature of this category:

But this part of physical health, it is mainly up to the nurse's, which is in our area, which we know even more than other professionals in other areas. (Nurse 2/interview)

Regarding medication administration, $100 \%$ of the participants attributed this action to the nurse, although $79 \%$ included the nursing assistant and technician in this role and $21 \%$ the doctor. As for medication monitoring (identification of side effects, signs and symptoms of intoxication and overdose), $82 \%$ reported that it was the nurse's responsibility; $44 \%$ included the nursing assistant/technician; $23 \%$ the doctor; and 15\% higher education professionals.

Thus, the association between nursing, physical care and responsibility for medication was clearly emphasized by the participants:

People look for medicine to solve problems and, when talking about medicine, they always think about nursing and the doctor. (Participant Social Worker 1/focus group)

I think that the professionals end up seeing the nurse, the nursing professional, as simply the person who applies the medication, the person who sees the medical prescription. (Nurse 2/interview)

Difficulties related to the training of nurses were mentioned by a nurse, who thought he was unprepared to perform emotional management:

The graduation leaves a lot to be desired and the post-graduation I did [in mental health], I didn't feel qualified to do this type of psychological care, so to speak. (Nurse 3/interview)

On the other hand, issues related to autonomy in the execution of actions, as well as to frustration due to the complexity of the care provided to users in mental suffering and deficient infrastructure, were mentioned by nurses as difficulties for professional practice: 
The work could go much further if we had autonomy, if our opinions, ideas, were taken more seriously, because, although management says it is democratic, that everyone has a voice, we realize that it is not quite like that [...] It is noticeable that the structure is totally deficient and it is not only the structure of the service, it is the structure of the government itself, of the management itself. [...] / believe that the biggest problem with the service is the infrastructure. (Nurse 3/interview)

\section{DISCUSSION}

The results showed that most of the participants had a broad perception of the actions developed by nursing in the field of mental health and in the core of the profession.

Interdisciplinarity was the connector of the study categories. In this sense, the purpose of interdisciplinary actions is to overcome the fragmentation of care and promote the integration of different professions. Such actions are important both for the joint work process that provides comprehensive care to the user and for overcoming the traditional model of psychiatric care ${ }^{(11)}$.

The interdisciplinary actions mentioned by the participants were home visits, active participation in team meetings, welcoming, conducting groups, therapeutic workshops, as well as acting as a reference professional. These findings corroborate a previous study on the work of nurses in mental health ${ }^{(12)}$.

It was also shown that interdisciplinarity was considered to guide actions in the services, although some nurses reported that, under such guidance, they tended to perform tasks that were not their responsibility.

It is worth mentioning that the activities of integral assistance and in a patient care team are provided for in the Professional Practice Law and in the Code of Ethics for Nurses ${ }^{(13-14)}$, but in the context of mental health, this issue still needs broader debates to deepen the understanding of the concepts of integrality and interdisciplinarity. It is a discussion that could also more effectively guide professional practice in this field and more clearly delimit the core competencies of the profession in the context of mental health.

It is worth mentioning that the perception of some nurses that "everyone does the same things", in addition to denoting possible difficulties in defining professional specificities, suggests a distorted conception of interdisciplinarity.

Interdisciplinarity does not necessarily correspond to a situation in which all professionals perform the same actions, because the specific and diverse contribution of each core of profession in the actions is the element that will confirm the interdisciplinary nature of work in the field of mental health. This highlights the importance of each team member having a clear understanding of the competencies of his/her professional core (11-12). $^{\text {. }}$

In the midst of this discussion, the Regional Nursing Council (Coren)/SP instituted, in December 2015, a technical group to discuss nursing care in the scope of mental health. One of the proposals arising from such discussions was the flexibility so that the Systematization of Nursing Care (SNC) could be inserted in the STP, so that the medical record also follows the interdisciplinary logic, because the evaluation and prescription of nursing care would be part of the evaluation of other professionals ${ }^{(15-16)}$.

The consolidation of the recommendations proposed by this work group would favor the interlocution of nursing actions in interdisciplinary work, contributing for the technical actions arising from the curative model to be reorganized, reframed and operationalized under the aegis of psychosocial care.

The difficulty for nurses to recognize their professional identity specifically in the context of mental health corroborates the current legislation, because the private attributions delimited by Coren/SP to nurses are scarce compared to the attributions of this professional as a member of the health team ${ }^{(13)}$.

Another important contribution in relation to the practice of nursing in mental health in the current scope concerns Resolution no. 599/2018 of the Federal Nursing Council (COFEN), which delimits the competencies of the nursing team, in a sign of advances in this profession in its practical and theoretical appropriation in that area. The Resolution highlights the managerial, care competence of nurses, with a focus on practices under the aegis of psychosocial care, in addition to valuing them as an active member of the patient care team ${ }^{(16)}$.

Despite this and corroborating the results of the present study, this Resolution does not make it evident that some practices should be discriminated as specific duties of this professional(16). That is, it is understood that, even in the face of a list of interdisciplinary activities, there are specific actions that the nurse needs to perform for such activities to materialize. In this sense, nursing consultation assumes an important role, as it promotes the performance of essential practices for the integration of aspects related to physical and psychosocial health.

Examples of practices considered essential: contextualizing the planning of care and social reintegration to the socio-financial condition, identifying the support network for rehabilitation, making sure the patient's understanding of the use of psychotropic drugs and managing possible side effects, monitoring any possible effects variations in weight and vital signs resulting from the use of these medications, identify problems related to libido in the course of the disease and drug treatment.

In addition, they are part of the list of private tasks that can be performed during the nursing consultation: advice on the essential information to be provided by the user in consultations with other professionals and discuss possibilities of adapting the lifestyle to the limitations imposed by the disorder or by the drug treatment.

Furthermore, nursing observations in the different contexts of the clinical setting (workshops, groups, meals, hygiene and selfcare activities and during sleep/rest), including at home and in the territory, are also essential private tasks to maintain psychosocial integrity, physical health and user rehabilitation.

Regarding the unpreparedness for the emotional management of patients, expressed by one of the participants, it may signal the need for greater appreciation of relational skills during the training of nurses, both in the disciplines that address mental health in undergraduate courses and in the training of specialist nurses in mental health. Previous studies have also pointed out that many professionals, even having specialization in the area, manifest similar feelings ${ }^{(3-4,17-18)}$.

Under this premise, it is understood that additional studies are needed to analyze the possible causes of this gap between theory and practice that has permeated the nurses' actions in the area; certainly, issues related not only to content, but also to teaching strategies, have contributed to this.

On the other hand, despite the difficulties in operationalizing the concept of interdisciplinarity and the fragile delimitation 
between the core and field actions identified in the present study, nurses were mentioned as facilitators of interdisciplinary care. They are mediators of team conflicts and emotional, physical, family and collective situations in relation to users, in addition to being responsible for carrying out management/bureaucracy activities. Such activities highlight the importance of this professional in psychosocial care and suggest the transcendence of his/her role, previously perceived as strictly related to physical health ${ }^{(17)}$.

The nurse was also mentioned as the professional most requested by the users and the team, which corroborates numerous previous studies that highlight him/her as the professional closest to the patient ${ }^{(18-21)}$.

The greater proximity of the nurse with the users, both for the attributions related to physical health and for the actions of the mental health field mentioned, deserves to be highlighted and denotes the central position that he/she seems to occupy in the care of the user. In this sense, his/her ability in handling the information of users who circulate among different professionals was highlighted. Such centrality assumes a relevant role in the preparation of the STP and favors the integration and resolution of the team's actions.

It is worth mentioning that, unlike the traditional psychiatric model, in which nursing was responsible for the keys to hospitals and nursing homes ${ }^{(22)}$, the nurse was described by the participants as an important "gateway" and "reference" for the user in the service.

It is noted that the change in the perception of the nurse's work accompanies the transition from the paradigms of biomedical care to psychosocial care. However, it is important to note that the mental health policy has been undergoing strong setbacks, as made official in Resolution no. 32/2017 of the Tripartite InterManagement Commission and in the Technical Note no. 11/2019 of the Ministry of Health ${ }^{(23-24)}$. Such regulations emphasize the outpatient care model, centered on medicalization and symptom control, to the detriment of the social reintegration of the user or the holistic care of his/her needs, which is in opposition to the interdisciplinary perspective and can harm the performance of nursing actions in services mental health.

It should be noted that the data collection was carried out prior to these regulations, so the notes of the participants must be understood considering this situation. However, the fact that they have already mentioned little autonomy to carry out their work raises an important reflection and that remains a key point in the discussion of the performance of this professional in different contexts of care, including mental health.

In this sense, the international campaign Nursing Now, created by the World Health Organization (WHO) and the International Council of Nurses (ICN), has as one of its objectives the awareness of government officials so that they value the nurse, with a view to participation crucial role of this professional in reaching global health goals ${ }^{(25)}$.
The campaign in force in more than 30 countries, currently supported by the Federal Nursing Council, established as national goals the increase in the visibility of the profession, the development of leadership, the search for improvements in working conditions for the class and greater investments in training professionals. Thus, such a campaign advocates for legitimate causes and pertinent to the country's political context and is expected to promote positive results that will certainly also be reflected in mental health work $^{(26)}$.

\section{Limitations of the study}

In relation to the limitations of the study, it is worth pointing out the fact that the sample consists only of professionals. It is understood that the inclusion of different interest groups would provide more in-depth discussions about the phenomenon studied. Despite this limitation, three different data collection techniques were used to apprehend the participants' perception in different ways.

\section{Contributions to the nursing field}

This study highlights the challenges of professional autonomy and highlights the importance of discussing some essential actions for nursing care in the field of mental health. In addition, it reveals that nursing consultations and observation in the different care settings represent crucial moments for the consolidation of such actions.

\section{FINAL CONSIDERATIONS}

Regarding the specific actions of the nurse, it was identified that, because mental health is an area in which interdisciplinary actions are primarily required under the psychosocial framework, some difficulties persisted among the participants in defining the actions of the professional groups in the context of mental health.

From the set of specific actions of the nurse, the participants referred mainly to the care of the body and physical health, issues that historically refer to the beginnings of psychiatric nursing. However, this professional was also mentioned as a "gateway" for care, facilitator and integrator of actions and as one who has more contact with the user, which denotes a likely change in perception in relation to the role traditionally attributed to this profession.

In terms of reflexivity, the fact that the study was developed by nurses stands out. This, on the one hand, enriched the heart of the discussions, expanding questions previously pointed out by other studies and contributing to the advancement of the practice. However, on the other hand, it may have culminated in biases resulting from the experience of these researchers in relation to the issues discussed.

\section{REFERENCES}

1. Muniz MP, Tavares CMM, Abrahão, AL, Souza AC. Nursing care in times of psychiatric reform. Rev Port Enferm Saúde Mental [Internet]. 2015 [cited 2017 Jan 8];(13):61-5. Available from: http://www.scielo.mec.pt/pdf/rpesm/n13/n13a08.pdf

2. Tavares CMM, Cortez EA, Muniz MP. Care in psychiatric hospital under the perspective of a nursing team. Rev RENE [Internet]. 2014 [cited 
2017 Jan 22];15(2):282-90. Available from: http://repositorio.ufc.br/bitstream/riufc/11634/1/2014_art_cmmtavares.pdf

3. Souza J, Luis MAV. Demands of mental health: nurses' perceptions of family health teams. Acta Paul Enferm [Internet]. 2012 [cited 23 Nov 2016];25(6):852-58. Available from: http://www.scielo.br/pdf/ape/v25n6/v25n6a05.pdf

4. Cortes J, Barros S, Antonacci M, Chiavagatti F, Willrich J. Knowledge and practices that integrate the teaching psychiatric nursing from the perspective of faculty nurses. Rev Port Enferm Saúde Mental [Internet]. 2014 [cited 18 Jan 2017];(12):34-2. Available from: http://www.scielo. mec.pt/pdf/rpesm/n12/n12a05.pdf

5. Costa-Rosa A. O modo psicossocial: um paradigma das práticas substitutivas ao modo asilar. In: Amarante P. (Org.). Ensaios: subjetividade, saúde mental, sociedade [Internet]. Rio de Janeiro: Fiocruz; 2000 [cited 28 Jan 2017];141-68. Available from: http://books.scielo.org/id/htjgj/ pdf/amarante-9788575413197-09.pdf

6. Saraceno, B. Libertando identidades: da reabilitação psicossocial à cidadania possível. Rio de Janeiro: Instituto Franco Basaglia/ TeCorá; 1999. 176 p.

7. Bardin L. Análise de Conteúdo. Lisboa, Portugal: Edições 70; 2009.

8. Amankwaa L. Creating protocols for trustworthiness in qualitative research. J Cult Divers[Internet]. 2016 [cited 2017 Feb 25];23(3):121-27. Available from: https://pubmed.ncbi.nlm.nih.gov/29694754/

9. Korstjens I, Moser A. Series: Practical guidance to qualitative research. Part 4: trustworthiness and publishing, European J General Pract. 2018;24(1):120-124. doi: 10.1080/13814788.2017.1375092

10. Campos GWS. Public health and collective health: field and core area for knowledge and practice. Ciênc. Saúde Colet [Internet]. 2000 [cited 2016 Feb 22];5(2):219-230. Available from: http://www.scielo.br/pdf/csc/v5n2/7093.pdf

11. Ferro LF, Silva EC, Zimmermann AB, Castanharo RCT, Oliveira FRL. Interdisciplinarity and intersectoriality in the Family Health Strategy and Nuclei of Support to Family Health: potentialities and challenges. Mundo Saúde[Internet]. 2014 [cited 2018 Feb 22];38(2):129-38. Available from: http://www.saocamilo-sp.br/pdf/mundo_saude/155562/A01.pdf

12. Anjos Filho NC, Souza AMPA. The workers' perceptions about the multiprofessional teamwork at a Psychosocial Care Center in Salvador, Bahia, Brazil. Interface [Internet]. 2017 [cited 2018 Feb 22];21(60):63-76. doi: 10.1590/1807-57622015.0428

13. Presidência da República (BR). Lei n. 7.498 de 25 de junho de 1986. Dispõe sobre o exercício da enfermagem, e dá outras providências. Diário Oficial da União, Brasilia (1986 jun. 26).

14. Conselho Federal de Enfermagem (BR). Aprova a reformulação do Código de Ética dos profissionais de enfermagem. Resolução COFEN n. ${ }^{\circ}$ 311, de 8 de fevereiro de 2007. Código de Ética dos Profissionais de Enfermagem. 2007.

15. Conselho Regional de Enfermagem de São Paulo. Relatório do Evento do GT de Saúde Mental para as boas práticas de Enfermagem: Sistematização da Assistência de Enfermagem [Internet]. São Paulo: COREN/SP, 2016 [cited 20 de nov 2018]. Available from: https://portal. coren-sp.gov.br/sites/default/files/relatorio\%20do\%20evento\%20sae\%2001\%2004\%20\%281\%29.pdf

16. Conselho Federal de Enfermagem (BR). Norma técnica para atuação da equipe de enfermagem em saúde mental e psiquiatria. Anexo da resolução COFEN № 0599, de 19 de dezembro de 2018.

17. Souza MC, Afonso MLM. Knowledge and practices of nurses in mental health: challenges in face of the Psychiatric Reform. Gerais Rev Interinst Psicol [Internet]. 2015 [cited 2018 Feb 20];8(2):332-47. Available from: http://pepsic.bvsalud.org/pdf/gerais/v8n2/v8n2a04.pdf

18. Spagnuolo RS, Juliani CMCM, Spiri WC, Bocchi SCM, Martins STF. O enfermeiro e a estratégia saúde da família: desafios em coordenar a equipe multiprofissional. Cienc Cuid Saude [Internet]. 2012 [cited 25 Feb 2018];11(2):226-34. Available from: http://www.periodicos.uem.br/ ojs/index.php/CiencCuidSaude/article/view/10445

19. Fracolli LA, Castro DFA. Nursing competence in the Primary Care: a focus on the humanization of the work process. Mundo Saúde [Internet]. 2012 [cited 2018 Dec 15];36(3):427-32. Available from: http://bvsms.saude.gov.br/bvs/artigos/mundo_saude/competencia_enfermeiro_ atencao_basica_foco.pdf

20. Soares MI, Camelo SHH, Resck ZMR, Terra FS. Nurses' managerial knowledge in the hospital setting. Rev Bras Enferm [Internet]. 2016 [cited 2018 Aug 16];69(4):676-83. Available from: http://www.scielo.br/pdf/reben/v69n4/0034-7167-reben-69-04-0676.pdf

21. Fernandes MC, Silva LMS, Silva MRF, Torres RAM, Dias MSA, Moreira TMMM. Identity of primary health care nurses: perception of "doing everything". Rev Bras Enferm [Internet]. 2018 [cited 2019 Mar 10];71(1):154-9. Available from: http://www.scielo.br/pdf/reben/v71n1/ pt_0034-7167-reben-71-01-0142.pdf

22. Aranha e Silva AL, Fonseca RMGS. Work process in mental health and the psycosocial area. Rev Latino-Am Enfermagem [Internet]. 2005 [cited 2016 Nov 22];13(3):441 49 Available from: http://www.scielo.br/pdf/rlae/v13n3/v13n3a20.pdf

23. Ministério da Saúde. Nota Técnica n 11/2019. Esclarecimentos sobre as mudanças na Política Nacional de Saúde Mental e nas Diretrizes da Política Nacional sobre Drogas. Diário Oficial da União 2019.

24. Comissão Intergestores Tripartite (CIT). Resolução no 32, de 14 de dezembro de 2017. Estabeleceu as Diretrizes para o fortalecimento da Rede de Atenção Psicossocial (RAPS). Diário Oficial da União 2017; 22 dez.

25. Cassiani SHB, Lira Neto JCG. Nursing Perspectives and the "Nursing Now" Campaign. Rev Bras Enferm [Internet]. 2018 [cited 2019 Mar 28];71(5):2351-52. doi:10.1590/0034-7167.2018710501

26. Arcêncio RA. Nursing as the profession of the future and the foundation of universal health systems. Rev Latino-Am Enfermagem [Internet]. 2018 [cited 2019 Mar 28];26:e3063. Available from: http://www.scielo.br/pdf/rlae/v26/pt_0104-1169-rlae-26-e3063.pdf 